ACTA THERIOLOGICA

Vol. 27, 14: 181-190, 1982

BISONIANA LXXIX

\title{
Immobilizing and Marking of the European Bison
}

\author{
Zbigniew A. KRASIŃSKI, Krystyna CABOŃ-RACZYŃSKA \& \\ Małgorzata KRASIŃSKA
}

\begin{abstract}
Krasiński Z. A., Caboń-Raczyńska K. \& Krasińska M., 1982: Immobilizing and marking of the European bison. Acta theriol., 27, 14: 181-190 [With 3 Tables \& Plates V-VI]

Immobilization and marking of the European bison Bison bonasus (Linnaeus, 1758) was carried out in the Białowieża Primeval Forest over the period from 1977-1980 in connection with ecological studies. At first the preparation Rompun (Bayer) was used in a $20 \%$ solution injected intra-muscularly in doses of $2-3 \mathrm{ml} / \mathrm{kg}$, but later Immobilon (Reckitt \& Colman) was administered, remote injected by a Telinject gun, either into animals enclosed in a corral or directly while amongst the herd. Immobilon was injected into 29 bison of both sexes from 1 to 6 years old. The average doses for males were $0.75 \mathrm{ml} / 100 \mathrm{~kg}$, and for females $1 \mathrm{ml} / 100 \mathrm{~kg}$ of body weight. Males succumbed within $4.6(2-12)$ minutes, and females within $6.2(3-16)$ minutes after injection. After administering the antidote (Revivon) in the same doses as Immobilon males regained their physical powers within $10.0(5-17)$ minutes and females within $7.5(5-12)$ minutes. The bison were marked by means of ear-tags or by freeze-branding number with liquid nitrogen on the rump. Marking with ear-tags was not very effective, as $60 \%$ of the tags were lost within 2 years, while good results were obtained by freezebranding for $1.30-2.30$ minutes. Out of the total number of 31 brands made 22 , i.e. $71 \%$, were clearly visible. In $198010 \%$ of the bison population in the Białowieża Forest were marked.

[Białowieża National Park, 17-230 Białowieża, Poland (ZAK) and Mammals Research Institute PASc., 17-230 Białowieża (KCR, MK)]
\end{abstract}

\section{INTRODUCTION}

Observations of individually marked animals are necessary in order to obtain detailed information on the organization and structure of the bison population, to define the home ranges of groups and individuals, and to trace seasonal migrations. It was therefore essential for this purpose to work out an immobilization technique and methods for permanent marking of the animals. The purpose of this study is to present the results of experiments carried out with the aim of achieving a remote immobilization and marking technique for bison. 
The first attempts at marking representatives of the genus Bison were carried out in Canada, marking buffalo in the Wood Buffalo National Park (Stelfox, 1976). In Poland marking bison for ecological studies was initiated in 1977 and continued in subsequent years. Attempts at immobilization were made earlier on using M 99 (etorphine hydrochloride) on bison in reserves (Kania et al., 1973).

\section{METHODS}

Individuals were chosen for marking from one of the two large groups formed by bison in the Białowieża Primeval Forest during the winter. Marking was carried out in March and April from 1977-1979 and in January 1980.

The age of the bison used for the experiments was defined by means of horn structure and body dimensions. The year of birth for bison up to three years of age was established accurately by means of the size and shape of the horns (Photo 1 - Plate V), and it was also possible to define, though less accurately, the age of $4-6$ year old bison using the same criteria.

During the first year of experiments (1977) the bison were enticed into and enclosed in corrals, and individuals taken from among them for marking, which was carried out in a special wooden cage. The animals were immobilized by a direct intramuscular injection of the Rompun preparation (Bayer) administered in a $20 \%$ solution. The animals' weight was estimated in accordance with weightage standards. After injection the bison became sufficiently calm to make it possible to apply ear-tags to both ears and to freeze-brand numbers using liquid nitrogen. From 1978-1980 Large Animal Immobilon (Reckitt \& Colman) was used to immobilize bison, each $\mathrm{ml}$ containing etorphine hydrochloride $2.45 \mathrm{mg}$ acepromazine maleate Vet. C. $10 \mathrm{mg}$, chlorocresol $0.1 \%$, administered by means of the pneumatic type Telinject gun. The bison were first enclosed in a corral, then immobilized and marked. The animals were released after they had regained their capacity for free movement. Not all the bison chosen for marking entered the corral, in which case they were immobilized directly in the herd and then marked. At the end of this procedure they were given as an antidote Large Animal Revivon (Reckitt \& Colman) containing in each $\mathrm{ml}$ : diprenorphine hydrochloride $3 \mathrm{mg}$, metheylene blue $0.001 \%$, chlorocresol $0.1 \%$, aften receiving which the bison rapidly regained their physical powers. There was thus no fear of the half-stupefied animal being attacked by other individuals.

Two types of ear-tag were used for marking, one made of hard plastic with a snap fastener, the other of soft plastic. In order to increase the size of the latter two were combined to produce one large tag (Photo 2 - Plate V). The numbers were at first entered in ink on the tags, and when this proved impermanent, the tags were cut out. Before the ear-tag was placed in position the concha was shaved and a hole made in it with a special punch. Yellow ear-tags measuring $9 \times 6 \mathrm{~cm}$ were used, as both size and colour ensured good visibility in the forest.

Freeze-branding consisted in shaving and freeing from grease the skin on the rump and applying a special marking iron (number) made of metal alloy forming 
a good conductor of low temperature. The number branded was $10 \mathrm{~cm}$ in size. The branding iron was cooled by keeping it in liquid nitrogen $\left(-196^{\circ} \mathrm{C}\right)$ for 10 minutes before applying to the skin. At first the number was cold-branded on one side only, but later on both sides of the rump. A total of 20 bison were successfully marked.

\section{IMMOBILIZATION}

Marking such large and strong ruminants as European bison made it necessary to use immobilization methods safe for people and animals. This became possible after introducting strongly-acting pharmacological preparations into normal practice. Rompun, the preparation used at first, produced the required immobilization with doses of $2-3 \mathrm{mg} / \mathrm{kg}$ of body weight. Within 3-10 minutes after injection the bison became quiet and marking could be carried out. Only two young animals given a dose of $3 \mathrm{mg} / \mathrm{kg}$ "fell asleep" for 1 hour. Nine bison from one year to 6 years old were marked in this way. They returned to normal after about 2 hours.

The best effects were obtained by using Immobilon, which acts effectively regardless of the bison's sex and age. It was used for 29 bison (Table 1). Average effective doses for males were $0.75 \mathrm{ml} / 100 \mathrm{~kg}$ of body

Table 1

Immobilization of the European bison using Immobilon/Revivon.

\begin{tabular}{lcccccc}
\hline \multicolumn{1}{c}{ Sex } & $\begin{array}{c}\text { No. of } \\
\text { animals }\end{array}$ & $\begin{array}{c}\text { Age } \\
\text { years }\end{array}$ & $\begin{array}{c}\text { Immobilon } \\
\text { dosis, ml }\end{array}$ & $\begin{array}{c}\text { Time lapse } \\
\text { for collapse, } \\
\text { min. }\end{array}$ & $\begin{array}{c}\text { Revivon } \\
\text { dosis, ml }\end{array}$ & $\begin{array}{c}\text { Time lapse to } \\
\text { recover standing } \\
\text { position, min. }\end{array}$ \\
\hline Males & 16 & $1-5$ & $1.5-4.5$ & $2-12$ & $1.5-4.5$ & $5-17$ \\
$\overline{\mathrm{x}}$ & & & & 4.6 & & 10.0 \\
SD & 13 & $2-6$ & $1.5-4.0$ & $3-16$ & $1.5-4.5$ & $5-12$ \\
Females & & & & 6.2 & & 7.5 \\
$\overline{\mathrm{x}}$ & & & & 4.1 & & 2.0 \\
SD & & & & &
\end{tabular}

weight, and for females $1 \mathrm{ml} / 100 \mathrm{~kg}$. These are doses similar to those which may be used for domestic cattle. On account of the wide safety margin between an effective and a lethal dose no fatal cases were noted, all operations being fully successful. After intramuscular injection the preparation was quickly absorbed and rapidly produced the required reaction. Within $2(1-4)$ minutes after the injection it was possible to observe the first symptoms of its action, producing snorting, tailflicking, stumbling walk, quivering of the muscles and subsidence on to the haunches. When the preparation was administered to animals in 2-Acta Theriologica 
the corral a characteristic symptom was for the animals to rest their heads on the fence and to press forward strongly against the obstacle, this being the expression of their attempt to remain standing. The animal next subsided on to its haunches and reclined in a physiological position. A recumbent position was reached by males on an average after $4.6 \pm$ 2.3 minutes, and by females after $6.2 \pm 4.1$ (Table 1 ). If the animal had been restless before injection the organism's reaction was weaker and time longer from injection until the animal lay down, for instance a 4-year old bull succumbed after 12 minutes, while a 5 -year old cow took 16 minutes to succumb. These two cases distinctly differed from the average (Table 1).

One of the components of Immobilon is acepromazine maleate, which relaxes the excessive tension of the parasympathetic system, and consequently prevents undue excitement during the first phase of the preparation's action. Some degree of excitement was observed, however, among bison enclosed in the corral before injection, but not excitement was observed in bison immobilized directly among the herd. In one case only a 2-year old heifer ran into the forest to a distance of about $200 \mathrm{~m}$. after injection.

An etorphine antagonist in the form of the preparation Revivon was used in each case, in amounts equal to Immobilon. The action of the antagonist was manifested by gradual resumption of reaction to external stimuli e.g. touch. After several attempts the animal rose to its feet, in the case of males after $10.0 \pm 3.4$ minutes, and after $7.5 \pm 2.0$ in females (Table 1). The bison returned to the herd and occasionally manifested even greater activity. They were not attacked by other individuals. No side-effects were found in 9 bison which were immobilized twice during two successive years. A very great advantage of etorphine hydrochloride is its effective action in minimal doses, which makes it possible to use a gun for remote injection.

\section{MARKING}

It is essential to mark bison with permanent and clearly visible marks in order to carry out observations of these animals at a later date. It was decided to use two methods of marking: with ear-tags and by freezebranding with liquid nitrogen.

\subsection{Ear-tags}

At first the bison were marked with an ear tag in one ear, and later 
on in the studies in both ears. The first series comprised 9 bison, but the ear-tag was retained for longer than one year in one cow only. The unsuitable material from which the ear-tags were made contributed to the low degree of effectiveness of this method. In later years ear-tags made of soft plastic were affixed to 20 bison ( 11 males and 9 females). In general, however, this method was not very effective. Out of 40 eartags used 24 i.e. $60 \%$ were lost within a period of $1-2$ years, while 16 ear-tags $(40 \%)$ were retained for longer (Table 2). The ear concha was not found to be torn in bison marked twice, but even so they had lost their ear-tags. It was found that ear-tags made of hard plastic were worn through in the place of contact with the ear concha.

Table 2

Results obtained by marking the European bison with ear-tags.

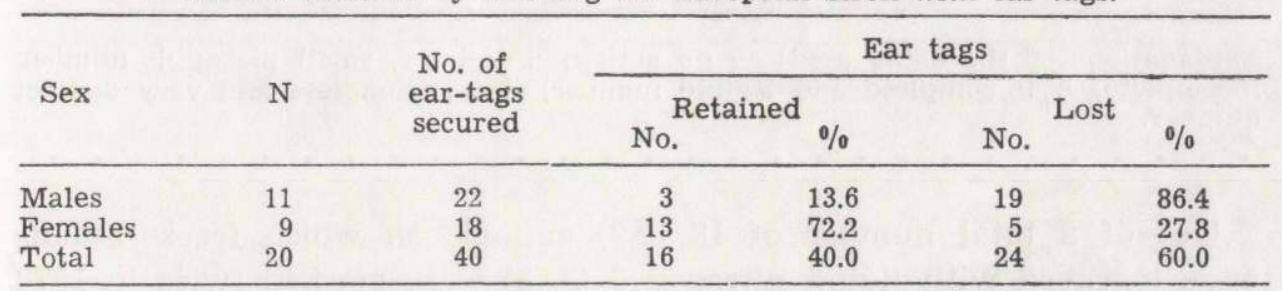

4.2. Freeze-branding Numbers with Liquid Nitrogen

A far more effective marking method is the action of low temperature on the animals' hide, which results in destruction of melanocytes and the appearance of white hairs. In small mammals it is sufficient to cool copper markers in a mixture of dry ice and alcohol (Hadow, 1972). The action of liquid nitrogen $\left(-196^{\circ} \mathrm{C}\right)$ is effective for large animals. In this case it is important, in order to obtain the desired effect, to define branding time correctly, so as not to cause destruction of the hair follicles. Before starting freeze-branding the hair was shaved and the site. abundantly swabbed with methyl alcohol.

During the first attempts at marking bison, freeze-branding time was $30-40 \mathrm{sec}$. for young animals and $50-60 \mathrm{sec}$. for adults. After about 50 days white hair was observed to grow on the brand site. Among 9 marked bisons only 3 had white hair. Prolongation of branding time to 2 minutes greatly improved the effect. Out of a total number of 11 bison marked in 1978 the numbers could be clearly seen in 9 individuals, but only faintly in the remainder. During the winter period the growth of the long winter coat limited the visibility of the numbers, but in spring after the moulting period the numbers could be seen far more 
clearly. During subsequent marking in 1980 it was found that prolongation of freeze-branding time may lead to destruction of the hair follicles and falling-out of hair, and consequently differences were made in the length of freeze-branding time depending on the sex and age of the bison, from $1.30 \mathrm{~min}$. to $2.30 \mathrm{~min}$. (Table 3 ).

\section{Table 3}

Results obtained by marking of the European bison with numbers freeze-branded with liquid nitrogen.

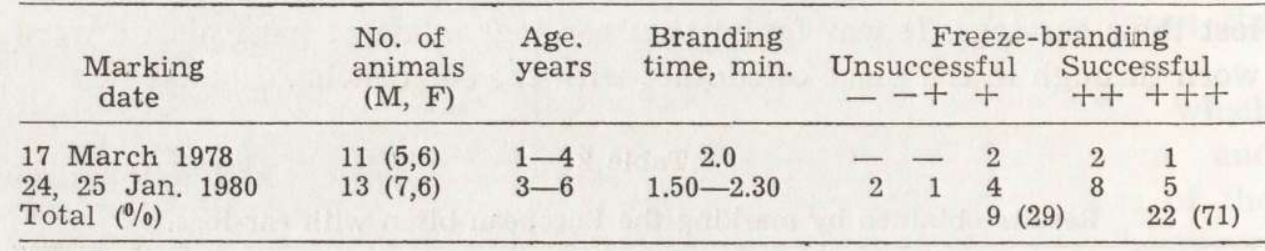

Explanations of the signs used: - no action; +- trace, small piece; + number incomplete; ++ complete and legible number; +++ complete and very distinct number.

Out of a total number of $18(9,9)$ animals on which freeze-brands were markerd with liquid nitrogen $6(3,3)$ were marked twice in 1978 and 1980, either in order to brand on both sides of the rump or to correct the brand. Subsequent field observation were made far easier when there were brands on both sides. Nine $(29 \%)$ out of a total number of 31 brands were unsuccessful, only parts of numbers impossible to decipher appearing after freeze-branding, while the remainder were legible and could be identified under field conditions (Table 3, Photo $3-$ Plate VI).

\section{DISCUSSION}

The effects of detailed studies on migrations, individual home ranges, group ranges and social relations depend to a great extent on the possibility of identifying given individuals. Identification by means of individual characteristics is limited, since it usually relates to a small number of random individuals (Klingel, 1967; Mukinya, 1976). Shaving the tail or mane, like painting numbers on the skin, may be useful for short-term observations (Pienaar et all., 1966).

In the case of European bison identification of individuals may be based on the shape and various defects of the horns, e.g. broken and crooked growth of horns. In occasional cases animals can be identified 
by means of other distinguished characteristics e.g. loss of part of the tail.

Applying paint to the horns has also been tried, but the paint stayed on only 2 months (McGillis et al., 1976). The horns of 3 bull bison were painted at Białowieża in the spring of 1976, but when one bull was caught again 8 months later, there were only traces of the paint left, while it proved completely impossible to identify the other two bulls.

Since European bison live in a forest habitat and are not very timid it was necessary to use a marking method which would make it possible to identify different individuals at a distance of about $50 \mathrm{~m}$. using field-glasses, since this is the distance to which under normal conditions the herd allows itself to be approached.

Permanent marking is also essential in ecological studies, which are usually carried out over long periods, and therefore the results obtained using ear-tags were unsatisfactory. Our experiments showed that about $60 \%$ of the bison lose their ear-tags within $1-2$ years. Loss of ear-tags has been observed in other large mammals, e.g. the antelope (Pienaar, 1969) and bison (McGillis \& Stelfox, 1976).

Another method is putting collars on the neck, as it is done with different species of antelopes, mooses and zebras (Pienaar et al., 1966; Klingel, 1967). This method was also applied on bisons (collars $4-5 \mathrm{~cm}$ wide) but it did not prove effective, neither did ear-tags (McGillis \& Stelfox, 1976).

One of the methods is to brand with a red hot branding iron, which has long been in use in the case of horses, but for appearance's sake is no longer employed.

In animals with a coloured coat the effect of low temperature began to be used for permanent marking, in order to cause bleaching of the hair. It was first used for domestic cattle and horses (Deskur \& Wierzchoś, 1974; Stelfox, 1976). It is a humanitarian method, the animals remain calm during the operation and when correctly done no lasting tissue damage is caused. In the Wood Buffalo National Park in Canada freezebranding with liquid nitrogen was used on 23 bison without the use of tranquillizing or anaesthetizing preparations. Branding time for young animals was $12 \mathrm{sec}$. and from 17-20 sec. for adult individuals (Stelfox, 1976). After one year a faint brand was observed in one bull only, and it would appear that the poor results were due to the shortlived action of low temperature. In the case of European bison branding time of $30-40 \mathrm{sec}$. for young animals and $50-60 \mathrm{sec}$. for adults gave similar results. It was not until the time of low temperature action was prolonged to $1.30-2.30 \mathrm{~min}$. that permanent marking was achieved.

It may be necessary to immobilize bison not only for marking, but 
also for other purposes. At first derivatives of phenothiazine such as Trankwilina (Polfa) or Combelen (Bayer) were used for this purpose, but in the case of large, strong and aggressive ruminants they failed to meet requirements, as large doses had to be given and only poor results were obtained. Chlorsuccylin (Polfa) has not been widely used on account of the small safety margin and lack of an antidote. A far better preparation proved to be Rompun (Bayer), but large doses had to be administered to bison to ensure full tranquilization, and particularly to get the animals into a recumbent position. In the case of adult bison, even when $20 \%$ solution was used it was necessary to apply the preparation several times, which was not always possible. The lack of an antidote left the animals under the influence of this preparation for a long time after injection. It was not until tebaine derivatives were used, at first in the form of the preparation M 99, and later Immobilon, that all-round immobilization of bison became possible. When medium doses of Immobilon were administered the bison lay down, in the physiological position, which prevents distension or choking as the result of food entering the respiratory passages. Immobilon has a highly analgesic action and during the operation it is not necessary to use anaesthetics. Successful immobilization was obtained in bison of various ages, from young animals from $1-3$ years old to a 20 -year old cow.

Acknowledgements: The authors wish to thank the Director and staff of the Animal Breeding and Insemination Station at Bielsk Podlaski for their help and for supplying liquid nitrogen for our studies. They also wish to thank the technical personnel of the Institute, Messrs W. Bajko and M. Szuma, and also the game wardens and breeders of the Białowieża National Park for their assistance in carrying out these studies.

\section{REFERENCES}

1. Deskur S. \& Wierzchoś E., 1974: Znakowanie koni przez wymrażanie numerów. Instrukcja wdrożeniowa Instytutu Zootechniki (5), Kraków.

2. Hadow H. H., 1972: Freeze branding: a permanent marking technique for pigmental mammals. J. Wildl. Manage., 36, 2: 645-649.

3. Kania F. B., Teuchmann J. K., Piwowarczyk S. \& Krasiński Z., 1973: Badania nad immobilizującym działaniem chlorowodorku etorpiny ( $M$ 99) na Bison bonasus L. oraz antagonizowanie tego działania chlorowodorkiem cyprenorfiny (M 285). Prz. zool., 17, 2: 242-247.

4. Klingel H., 1967: Sociale Organisation und Verhalten freilebender Steppenzebras. Z. Tierpsychol., 24: 580-624.

5. Mukinya J. G., 1976: An identification method for black rhinoceros (Diceros bicornis L.). E. Afr. Wildl. J., 14, 4: 335-338.

6. Pienaar U. de V., Niekerk J. W., Young E., Van Wyk P. \& Fairall N., 1966: The use of oripavine hydrochloride (M-99) in the drug immobilization and marking of wild African elephant (Loxodonta africana Blumenbach) in the Kruger National Park. Koedoe, 9: 108-124. 
7. Stelfox I. G., 1976: Freeze-branding bison for aerial identification, Wood Buffalo National Park 13 June 1975. [In: "Wood Buffalo National Park Bison Research 1972-76, 1976 Annual Report”]. Canadian Wildlife Service Parks Canada. Mimeo.

8. McGillis J. R. \& Stelfox J. G., 1976: Tagging, radio-collaring and marking bison. [In: "Wood Buffalo National Park Bison Research 1972-1976, 1976 Annual Report"]. Canadian Wildlife Service Parks Canada. Mimeo.

Accepted, April 14, 1982.

Zbigniew A. KRASIŃSKI, Krystyna CABOŃ-RACZYŃSKA, Małgorzata KRASIŃSKA

\section{UNIERUCHAMIANIE i ZNAKOWANIE ŻUBROW}

\section{Streszczenie}

W pracy przedstawiono technikę unieruchamiania żubrów oraz metody trwałego znakowania osobników. Znakowanie prowadzono w latach 1977-1980. Początkowo żubry zamykano $\mathrm{w}$ odłowni, a znakowanie przeprowadzano $\mathrm{w}$ specjalnej, drewnianej klatce. Do unieruchamiania zwierząt stosowano Rompun (Bayer) w roztworze $20 \%$. Ciężar ciała oceniano w przybliżeniu na podstawie wzorców wagowo-wiekowych (Fot. 1). Rompun stosowano u 9 żubrów w wieku 0,5-8 lat $w$ ) dawce $2-3 \mathrm{mg} / \mathrm{kg}$. W ciągu $3-10$ minut po injekcji obserwowano uspokojenie zwierząt tak, że można było je znakować.

Do obezwładnienia zastosowano następnie Immobilon (Reckitt \& Colman) podawany przy użyciu broni typu pneumatycznego firmy Telinject. Początkowo żubry zamykano $w$ odłowni, a następnie unieruchamiano je bezpośrednio $w$ stadzie. Immobilon zastosowano u 29 zwierząt w wieku $1-6$ lat, obu płci. Skuteczne dawki dla samca wynosiły $0,75 \mathrm{ml} / 100 \mathrm{~kg}$, a u samic $1 \mathrm{ml} / 100 \mathrm{~kg}$. Wszystkie próby były $\mathrm{w}$ pełni udane. Po injekcji samce kładły się po upływie średnio 4,6 min $(2-12)$, a samice $6,2 \mathrm{~min}$. (3-16). W każdym przypadku stosowano antidotum - Revivon w ilości równej podanemu Immobilonowi. Działanie Revivonu następowało u samców średnio po $10,0 \mathrm{~min}$. (5-17) u samic po 7,5 min (5-12) (Tabela 1).

Do znakowania użyto 2 typów kolczyków koloru żółtego, stosowanych w hodowli bydła zarodowego (Fot. 2) zakładanych początkowo do jednego ucha a następnie do obu uszu. Efektywność tej metody była niewielka, bo na 40 założonych kolczyków $-60 \%$ zostało zgubionych po upływie $1-2$ lat (Tabela 2 ).

Bardziej efektywne okazało się wymrażanie cyfr na skórze zadu ciekłym azotem znacznikami stosowanymi do znakowania bydła, oziębianymi przez 10 minut w ciekłym azocie $\left(-196^{\circ} \mathrm{C}\right)$. Na początku czas wymrażania wynosił u młodzieży 30-40 sek., u sztuk dorosłych $50-60$ sek. Po upływie 50 dni zaczynały wyrastać białe włosy w miejscu wymrażania. Tylko u 2 sztuk z 11 znakowanych wytworzyły się niekompletne piętna. Przedłużenie czasu wymrażania do $2 \mathrm{~min}$. dało lepsze wyniki (Tabela 3). $\mathrm{Z}$ ogólnej liczby 31 piętn $-22 \mathrm{tj}$. $71 \%$ było kompletne i czytelne. 


\section{EXPLANATIONS OF PLATES}

\section{Plate V}

Photo 1. Defining the age of bison by means of size and shape of horns. $\mathrm{a}-$ up to 1 year, b - up to 2 years, c - up to 3 years.

The horns of European bison are similar in shape in both sexes up to the age of 3 years.

Photo 2. Ear-tag made of plastic used for marking bison. These are standard eartags used for domestic cattle. Combining two ear-tags gives better visibility under field conditions.

\section{Plate VI}

Photo. 3. Mixed group of European bison in the Białowieża Primeval Forest. A cow marked by freeze-branding no. 10 on the rump and with ear-tag can be seen in the foreground. 


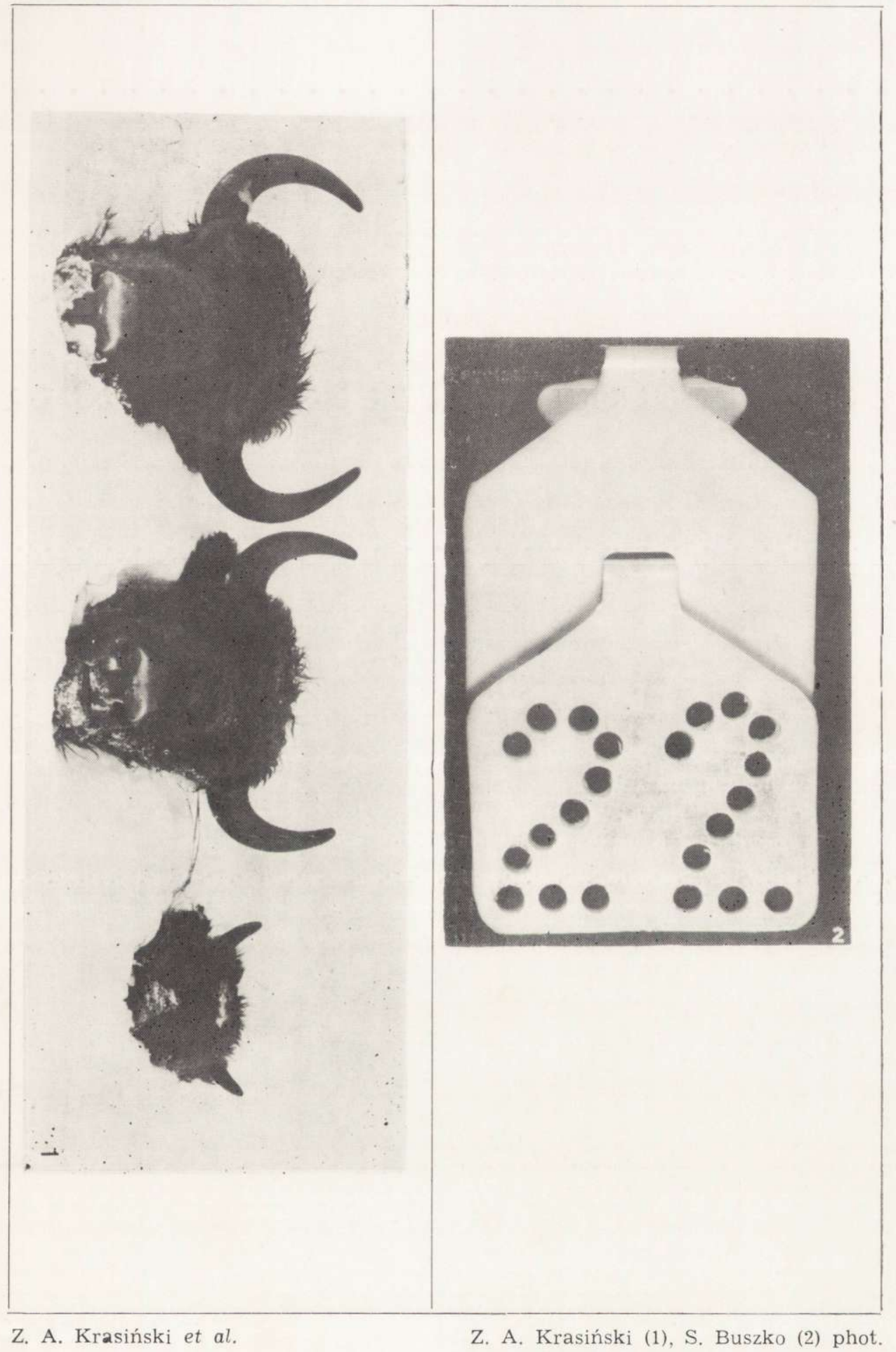




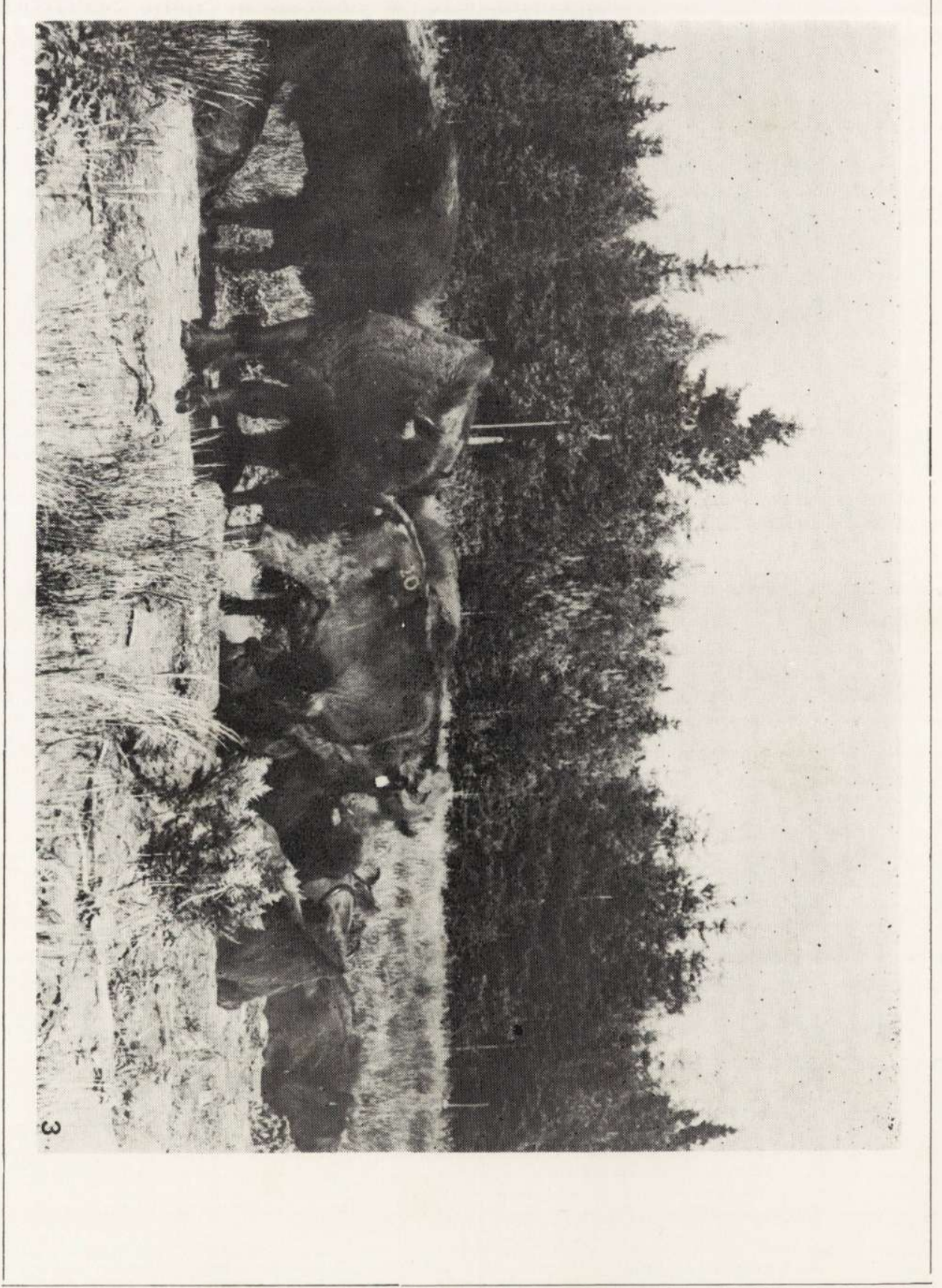

z. A. Krasiński et al.

Z. A. Krasiński phot. 